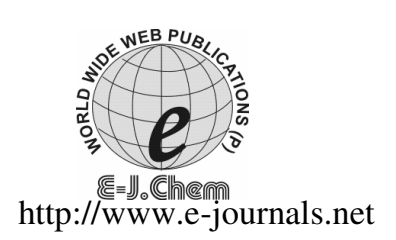

ISSN: 0973-4945; CODEN ECJHAO

E-Journal of Chemistry

2011, 8(1), 29-36

\title{
Synthesis and Structural Studies on Transition Metal \\ Complexes Derived from 4-Hydroxy-4-methyl-2- pentanone-1H-benzimidazol-2-yl-hydrazone
}

\author{
M.NEELAMMA, P.VENKATESWAR RAO* and G.H.ANURADHA \\ Department of Chemistry, R B V R Reddy Women's College \\ Narayanguda, Hyderabad-500029, India \\ *Department of Chemistry, Nizam College, Hyderabad-500001, A.P., India \\ pallapothulav@yahoo.com
}

Received 25 May 2010; Accepted 31 July 2010

\begin{abstract}
Transition metal complexes of $\mathrm{Cr}(\mathrm{III}), \mathrm{Fe}(\mathrm{III}), \mathrm{Mn}(\mathrm{II}), \mathrm{Co}(\mathrm{II}), \mathrm{Ni}(\mathrm{II})$, $\mathrm{Cu}$ (II) and $\mathrm{Zn}$ (II) with a tridentate ligand, 4-hydroxy-4-methyl-2-pentanone- $1 \mathrm{H}$ benzimidazole-2yl-hydrazone (H-HPBH) derived from the condensation of 2-hydrazinobenzimidazole and diacetone alcohol was synthesized. Characterization has been done on the basis of analytical, conductance, thermal and magnetic data, infrared, ${ }^{1} \mathrm{H}$ NMR, electronic, mass and ESR spectral data. From analytical and thermal data, the stoichiometry of the complexes has been found to be 1:1 (metal: ligand). Divalent complexes have the general formula $\left[\mathrm{M}(\mathrm{HPBH}) \mathrm{Cl}\left(\mathrm{H}_{2} \mathrm{O}\right)_{2}\right]$ in octahedral geometry, $[\mathrm{M}(\mathrm{HPBH}) \mathrm{Cl}]$ in tetrahedral and square planar stereochemistries and trivalent complexes $\left[\mathrm{M}(\mathrm{HPBH}) \mathrm{Cl}_{2}\left(\mathrm{H}_{2} \mathrm{O}\right)\right]$ in octahedral disposition. Infrared spectral data suggest that the ligand HPBH behaves as a monobasic tridentate ligand with $\mathrm{N}$ : $\mathrm{N}$ : O donor sequence towards the metal ions. On the basis of the above physicochemical data, octahedral, tetrahedral and square planar geometries were assigned for the complexes. The ligand and metal complexes were screened for their physiological activities against E. coli and S. aureus. The order of physiological activity has been found to be $\mathrm{Cu}$ (II) $>\mathrm{Ni}$ (II) $>\mathrm{Zn}$ (II) $>\mathrm{Co}$ (II) $>\mathrm{Cr}$ (III) $>\mathrm{Mn}$ (II) $>\mathrm{Fe}$ (III) $>$ ligand against E.coli and $\mathrm{Ni}(\mathrm{II})>\mathrm{Cu}(\mathrm{II})>\mathrm{Zn}(\mathrm{II})>\mathrm{Mn}(\mathrm{II})>\mathrm{Cr}(\mathrm{III})>\mathrm{Fe}(\mathrm{III})>$ $\mathrm{Co}(\mathrm{II})>$ ligand against $S$. aureus.
\end{abstract}

Keywords: 2-Hydrazinobenzimidazole, Diacetone alcohol, E.coli, S. aureus.

\section{Introduction}

The coordination chemistry of nitrogen-oxygen donor ligands is an interesting area of research ${ }^{1}$. A great deal of attention in this area has been focused on the complexes formed by transition metal ions with hydrazones ${ }^{2-7}$. The remarkable biological activity of acid hydrazides, a class of Schiff bases, their corresponding aroyl hydrazones, and the dependence 
of their mode of chelation with transition metal ions present in the living system has been of significant interest in the past ${ }^{8-11}$. The chemistry of metal complexes with the Schiff base ligands has become a rapidly growing area of research ${ }^{12}$. Schiff bases play an important role in inorganic chemistry as they form stable complexes with most transition metal ions ${ }^{13-14}$. The remarkable biological activity of aroyl hydrazones and their mode of chelation with transition metal ions present in the living systems have been of significant interest ${ }^{15-16}$. The coordination chemistry and physiological activities of benzimidazole derivatives and their metal complexes are of recent interest ${ }^{17-22}$. Hydrazones of benzimidazole are biologically active against different bacteria, fungi and microbes ${ }^{23-26}$. The hydrazones act as anticancer and antitumor agents ${ }^{27-28}$. The coordination compounds of aroyl hydrazones have been reported to act as enzyme inhibitors ${ }^{29}$ and are useful due to their pharmacological applications ${ }^{30}$. The ligand in the present investigation 4-hydroxy-4-methyl-2-pentanone-1Hbenzimidazole-2yl-hydrazone $(\mathrm{H}-\mathrm{HPBH})$ is a potential chelating agent ${ }^{31}$. Besides its chelating ability it has promising antimicrobial activities ${ }^{32}$. In view of this, the work on the title compounds was undertaken and the results are reported here.

\section{Experimental}

\section{Synthesis of ligand}

Diacetone alcohol (0.01 mole, $0.116 \mathrm{~g})$ was added to a solution of 2-hydrazine benzimidazole $(0.01,0.148 \mathrm{~g})$ in methanol $(100 \mathrm{~mL})$. The mixture was heated under reflux for $3 \mathrm{~h}$. The mixture was then poured into ice-cold water. The violet colored needles separated out were filtered and washed with small amount of aqueous alcohol. The compound was dried in vacuum and recrystallized from aqueous methanol.

\section{Synthesis of metal complexes}

The metal chelates were prepared by refluxing the methanol solutions of the respective metal chlorides (0.01 mole) and H-HPBH (0.01mole, $0.246 \mathrm{~g})$ on a water bath for $\mathrm{ca} 4 \mathrm{~h}$. The $\mathrm{pH}$ of the solution was adjusted to 7 by drop wise addition of $10 \%$ methanol- ammonia solution. Upon cooling the product, the metal chelates were separated out .The products were washed with methanol, followed by petroleum ether $\left(60-80{ }^{\circ} \mathrm{C}\right)$ and dried in vacuum.

\section{Materials and methods}

All the metal salts and solvents used were E.Merck analar products. Mercapto benzimidazole, hydroxylamine and diacetone alcohol were Fluka reagents. All other chemicals used were of AR grade.

Elemental analyses $(\mathrm{C}, \mathrm{H}, \mathrm{N}$, and $\mathrm{Cl})$ were carried out using micro analytical techniques on Heraeus C H N rapid analyzer. Metal estimations were done on a Perkin Elmer 2380 atomic absorption spectrometer. Conductivity measurements were carried out on Elico digital conductivity meter model No: CM -180.The magnetic susceptibility measurements were done on a Faraday balance $(\mathrm{CAHN}-7600)$ using $\mathrm{Hg}\left[\mathrm{Co}(\mathrm{SCN})_{4}\right]$ as calibrant. TGA and DTA data were recorded on Leeds and Northrup USA instrument. Infrared spectra were recorded on a Perkin Elmer 1600 FT infrared spectrometer in nujol mull. The electronic spectra were recorded on a Shimadzu UV-160 Spectrometer. ${ }^{1} \mathrm{H}$ NMR data was recorded on a Varian XL $200 \mathrm{MHz}$ NMR spectrometer using $\mathrm{CDCl}_{3}$ and $\mathrm{DMSO}-\mathrm{d}_{6}$ as solvents. ESR spectra were recorded at room temperature on Jeol-SE-3X, ESR spectrometer using DPPH as standard.

\section{Results and Discussion}

All the metal chelates except $\mathrm{Zn}(\mathrm{II})$ complex are colored. All of them are stable towards air and moisture. They decompose at high temperatures $(>723 \mathrm{~K})$. The metal complexes are 
insoluble in common organic solvents like benzene, chloroform, carbon tetrachloride, hexane, methanol, ethanol, acetone etc. They are soluble in DMF, dioxane and DMSO. The analytical data (Table 1) of the metal complexes show that all the metal chelates have 1:1 metal to ligand stoichiometry. Conductance measurements were carried out to ascertain the electrolytic/non-electrolytic nature of metal complexes. Molar conductance values of the complexes in 0.001 M DMF solutions at room temperature suggest their non-electrolytic nature. The analytical data reveal that the complexes have general formulae such as $\left[\mathrm{M}(\mathrm{HPBH}) \mathrm{Cl}\left(\mathrm{H}_{2} \mathrm{O}\right)_{2}\right],[\mathrm{M}(\mathrm{HPBH}) \mathrm{Cl}]$ and $\left[\mathrm{M}(\mathrm{HPBH}) \mathrm{Cl}_{2}\left(\mathrm{H}_{2} \mathrm{O}\right)\right]$, where $\mathrm{L}=\mathrm{HPBH}$.

Table 1. Analytical and conductivity data of the ligand and metal complexes

\begin{tabular}{|c|c|c|c|c|c|c|}
\hline \multirow{2}{*}{$\begin{array}{c}\text { Ligand/ } \\
\text { Complex }\end{array}$} & \multirow{2}{*}{ Carbon } & \multicolumn{3}{|c|}{ Found (Calcd) \% } & \multirow{2}{*}{ Metal } & \multirow{2}{*}{$\begin{array}{c}\wedge_{\mathrm{M}} \\
\mathrm{mhos} \\
\mathrm{cm}^{2} \mathrm{~mol}^{-1}\end{array}$} \\
\hline & & Hydrogen & Nitrogen & Chloride & & \\
\hline HPBH & 63.38 & 7.28 & 22.72 & - & - & - \\
\hline$\left[\mathrm{C}_{13} \mathrm{H}_{18} \mathrm{~N}_{4} \mathrm{O}\right]$ & $(65.34)$ & $(7.32)$ & $(22.76)$ & & & \\
\hline $\mathrm{Cr}$ (III) complex & 40.39 & 4.19 & 14.47 & 18.33 & 13.54 & 40 \\
\hline$\left[\mathrm{CrC}_{13} \mathrm{H}_{19} \mathrm{~N}_{4} \mathrm{O}_{2} \mathrm{Cl}_{2}\right]$ & $(40.42)$ & $(4.92)$ & (14.51) & (18.39) & (13.44) & \\
\hline $\mathrm{Mn}(\mathrm{II})$ complex & 41.96 & 5.56 & 15.04 & 9.50 & 14.70 & 18 \\
\hline$\left[\mathrm{MnC}_{13} \mathrm{H}_{21} \mathrm{~N}_{4} \mathrm{O}_{3} \mathrm{Cl}\right]$ & $(42.00)$ & $(5.65)$ & $(15.07)$ & $(9.55)$ & (14.78) & \\
\hline $\mathrm{Fe}(\mathrm{III})$ complex & 39.88 & 4.81 & 14.38 & 18.80 & 14.24 & 57 \\
\hline$\left[\mathrm{FeC}_{13} \mathrm{H}_{19} \mathrm{~N}_{4} \mathrm{O}_{2} \mathrm{Cl}_{2}\right]$ & $(40.02)$ & $(4.87)$ & (14.31) & $(18.21)$ & $(14.31)$ & \\
\hline Co(II) complex & 45.89 & 4.85 & 16.57 & 10.35 & 17.25 & 32 \\
\hline$\left[\mathrm{CoC}_{13} \mathrm{H}_{17} \mathrm{~N}_{4} \mathrm{OCl}\right]$ & $(45.96)$ & $(5.00)$ & $(16.49)$ & $(10.45)$ & $(17.35)$ & \\
\hline $\mathrm{Ni}(\mathrm{II})$ complex & 41.58 & 5.55 & 14.87 & 9.40 & 15.70 & 29 \\
\hline$\left[\mathrm{NiC}_{13} \mathrm{H}_{21} \mathrm{~N}_{4} \mathrm{O}_{3} \mathrm{Cl}\right]$ & $(41.53)$ & (5.59) & (14.92) & $(9.46)$ & (15.64) & \\
\hline $\mathrm{Cu}(\mathrm{II})$ complex & 45.31 & 4.89 & 16.25 & 10.22 & 18.41 & 26 \\
\hline$\left[\mathrm{CuC}_{13} \mathrm{H}_{17} \mathrm{~N}_{4} \mathrm{OCl}\right]$ & $(45.34)$ & (4.94) & (16.27) & $(10.31)$ & $(18.45)$ & \\
\hline $\mathrm{Zn}(\mathrm{II})$ complex & 40.80 & 5.45 & 14.62 & 9.22 & 17.00 & 11 \\
\hline$\left[\mathrm{ZnC}_{13} \mathrm{H}_{21} \mathrm{~N}_{4} \mathrm{O}_{3} \mathrm{Cl}\right]$ & $(40.85)$ & $(5.50)$ & $(14.66)$ & $(9.29)$ & (17.10) & \\
\hline
\end{tabular}

\section{${ }^{1} \mathrm{H} N M R$ data}

The ${ }^{1} \mathrm{H}$ NMR spectrum of HPBH was recorded in DMSO- $\mathrm{d}_{6}$ solution. $\delta 11.3 \mathrm{NH}$ proton (s, $1 \mathrm{H}$, of Benzimidazole), a multiplet at $\delta 6.95-\delta 7.25$ is due to aromatic protons, $\delta 1.2$ (s, $3 \mathrm{H}$, $\left.\mathrm{CH}_{3}\right), \delta 1.3\left(\mathrm{~s}, 3 \mathrm{H}, \mathrm{CH}_{3}\right)$. The methyl groups are non-equivalent and are present in tautomeric form, $\delta 2.1\left(\mathrm{~d}, 3 \mathrm{H}, \mathrm{CH}_{3}\right), \delta 2.5\left(\mathrm{~m}, 2 \mathrm{H}, \mathrm{CH}_{2}\right), \delta 8.4(\mathrm{~s}, 1 \mathrm{H}, \mathrm{NH})$ and $\delta 12.1(\mathrm{~s}, 1 \mathrm{H}, \mathrm{OH})$. The ${ }^{1} \mathrm{H}$ NMR signals are in correlation with the expected structure ${ }^{33}$ (Figure 1).<smiles>C/C(CC(C)(C)O)=N/Nc1nc2ccccc2[nH]1</smiles>

Figure 1. Structure of the ligand HPBH

\section{Infrared spectral studies}

The infrared spectrum of the free ligand shows a broad strong band in the region 3450 $3000 \mathrm{~cm}^{-1}$ with stretching vibrations at 3450,3330 and $3000 \mathrm{~cm}^{-1}$ which are assignable to $v \mathrm{NH}$ (free), $\mathrm{vNH}$ (ring) and $\mathrm{vOH}$ (hydrogen bonded). Strong bands located at 1634 and 1579 $\mathrm{cm}^{-1}$ can be assigned to $\mathrm{VC}=\mathrm{N}$ (exo) and $\mathrm{VC}=\mathrm{N}$ (ring). Sharp peaks at $1269 \mathrm{~cm}^{-1}$ can be adjudged mainly due to $\mathrm{VC}-\mathrm{O}$ (enolic) stretching frequency ${ }^{34}$. The $\mathrm{VN}-\mathrm{N}$ band is located at $1018 \mathrm{~cm}^{-1}$. 
The IR spectra of all the complexes show a general broadening and merging of $\mathrm{vNH}$ and $\mathrm{vOH}$ bands. In the spectra of all the complexes, no band is observed around $3000 \mathrm{~cm}^{-1}$ which was present in the free ligand and it suggests the cleavage of intramolecularly $\mathrm{H}$ bonded $\mathrm{vOH}$ with subsequent deprotonation and coordination through oxygen of $\mathrm{OH}$ group. It is further substantiated by the upward shift of $10-20 \mathrm{~cm}^{-1}$ in $v \mathrm{C}-\mathrm{O}$ (enolic) frequency. This further confirms the participation of oxygen of enolic group in complex formation ${ }^{35}$. A negative shift in $\mathrm{vC}=\mathrm{N}$ (exo) at $1634 \mathrm{~cm}^{-1}$ and $\mathrm{vC}=\mathrm{N}$ (ring) at $1579 \mathrm{~cm}^{-1}$ to the extent of $20-30 \mathrm{~cm}^{-1}$ in the spectra of the chelates suggest the involvement of azomethine nitrogen free as well as azomethine nitrogen benzimidazole ring in coordination ${ }^{36}$.

In the spectra of all the complexes, there is an upward shift in $v \mathrm{~N}-\mathrm{N}$ by $10-30 \mathrm{~cm}^{-1}$, which further supports the involvement of azomethine nitrogen of hydrazine chain in coordination ${ }^{37}$. The peak at $740 \mathrm{~cm}^{-1}$, which is assigned to the $\mathrm{NH}$ out of plane deformation vibration in the free ligand, is not altered on chelation. It reveals the non - participation of imine nitrogen in coordination.

The spectra of all the chelates show a broad band in the region $3300-3000 \mathrm{~cm}^{-1}$, which can be attributed to $\mathrm{vOH}$. This supports the presence of coordinated water in $\mathrm{Cr}(\mathrm{III}), \mathrm{Fe}(\mathrm{III})$, $\mathrm{Mn}(\mathrm{II}), \mathrm{Ni}(\mathrm{II})$ and $\mathrm{Zn}(\mathrm{II})$ complexes. The rocking modes further supports the presence of coordinated water and waging modes observed in the range $880-930 \mathrm{~cm}^{-1}$ and $670-400 \mathrm{~cm}^{-1}$ respectively ${ }^{38-39}$ further substantiates the presence of coordinated water and reveals the absence of lattice water. These non-ligand bands can be interpreted to the presence of coordinated water. The absence of vibration modes in the range of $3500-3200 \mathrm{~cm}^{-1}$ and $1670-1580 \mathrm{~cm}^{-1}$ is a clear evidence for the absence of lattice water.

The far IR spectra of all the metal chelates contain non-ligand bands around 240-280 $\mathrm{cm}^{-1}$ and these are assigned to $\mathrm{vM}-\mathrm{Cl}$. The spectra of all the complexes show nonligand bands in the region $460-640 \mathrm{~cm}^{-1}$. These are assigned to $v \mathrm{M}-\mathrm{O}$ and $\mathrm{vM}-\mathrm{N}$ bands ${ }^{40-41}$. Based on the IR data it is inferred that the ligand HPBH behaves as a monobasic tridentate ligand with $\mathrm{O}: \mathrm{N}$ : $\mathrm{N}$ donor sequence.

\section{Mass Spectral data}

The mass spectrum of the ligand shows its characteristic peaks at $\mathrm{m} / \mathrm{z}$ values: $91,104,112,118,130,133,174,228$ and 246. These are in accordance with the proposed structure of the ligand (Figure 2).

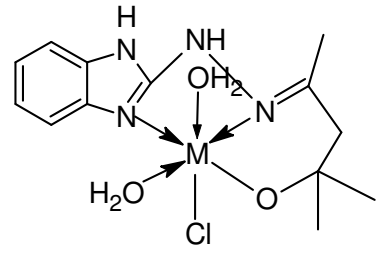

Figure 2. Structure of the metal complexes, where $\mathrm{M}=\mathrm{Mn}(\mathrm{II}), \mathrm{Ni}(\mathrm{II})$ and $\mathrm{Zn}(\mathrm{II})$

\section{Thermogravimetric and differential thermal analyses}

The thermal stability and decomposition temperature of the complexes were studied in air by simultaneous recording of TG and DTA curves. The measurements were made at a heating rate of $10 \mathrm{~K} \mathrm{~min}^{-1} .100 \mathrm{mg}$ samples were heated in platinum crucibles in air in the temperature range 300-1273 K with TG sensitivity of $100 \mathrm{mg}$, full scale. Thermo gravimetric analysis was carried out to confirm the presence of coordinated water. It shows a weight loss of one mole of coordinated water per mole of the complex with respect to the trivalent 
complexes. The loss has been found to be in one step. One endothermic peak was observed in differential thermal analysis. The loss of water occurs at $433 \mathrm{~K}$ for $\mathrm{Cr}(\mathrm{III})$ and at $453 \mathrm{~K}$ for $\mathrm{Fe}(\mathrm{III})$ complexes. In bivalent complexes $\mathrm{Mn}$ (II), Ni(II) and $\mathrm{Zn}$ (II) the weight loss is observed to be two moles of coordinated water per mole of the complex. The loss of water occurred in one step ${ }^{42}$. It occurs at $443 \mathrm{~K}$ for $\mathrm{Mn}$ (II), $453 \mathrm{~K}$ for Ni(II) and $463 \mathrm{~K}$ for $\mathrm{Zn}$ (II) complexes $^{43}$. The complexes have decomposition temperatures in the range $723 \mathrm{~K}-825 \mathrm{~K}$. The complexes have lost small molecules like $\mathrm{H}_{2} \mathrm{O}, \mathrm{CH}_{3} \mathrm{OH}, \mathrm{HCl}$ and $\mathrm{Cl}_{2}$ during the process of thermal treatment. Some phase changes in the solid state are also observed.

\section{Magnetic susceptibility measurements}

The magnetic moments are measured at room temperature i.e., at $300 \mathrm{~K}$. The magnetic moments are 3.85, 5.95, 5.92 and 3.42 B.M. for $\mathrm{Cr}(\mathrm{III}), \mathrm{Mn}$ (II), and $\mathrm{Fe}(\mathrm{III})$ and $\mathrm{Ni}$ (II) respectively. They correspond to $\mathrm{d}^{3}, \mathrm{~d}^{5}, \mathrm{~d}^{5}$ and $\mathrm{d}^{8}$ configurations of the complexes respectively ${ }^{44}$. As the magnetic moments correlate very well with the mononuclear complexes, low temperature magnetic measurements were not carried out. Subnormal magnetic moments have not been obtained. Metal-Metal interactions were not visualized. Hence Magnetic moments were not studied at low temperatures or liquid nitrogen temperatures. The complexes are assigned with a high spin octahedral geometry. Co(II) complex exhibits a magnetic moment of 4.2 B.M. This higher value is attributed to the orbital magnetic moment. The $\mathrm{Cu}$ (II) complex shows a magnetic moment of 2.15 B.M. This value supports the square planar geometry ${ }^{45}$.

\section{Electronic spectral studies}

The electronic spectrum of $\mathrm{Cr}$ (III) complex shows three intense bands centered at 17290, 22727 and $25000 \mathrm{~cm}^{-1}$. The first band can be assigned to ${ }^{4} \mathrm{~A}_{2 \mathrm{~g}} \rightarrow{ }^{4} \mathrm{~T}_{2 \mathrm{~g}}(\mathrm{~F})$ transition and the second band is assigned to ${ }^{4} \mathrm{~A}_{2 \mathrm{~g}} \rightarrow{ }^{4} \mathrm{~T}_{1 \mathrm{~g}}(\mathrm{~F})$ and the third can be attributed to ${ }^{4} \mathrm{~A}_{2 \mathrm{~g}} \rightarrow{ }^{4} \mathrm{~T}_{1 \mathrm{~g}}(\mathrm{P})$ transition respectively. These transitions support octahedral geometry around the $\mathrm{Cr}$ (III) complex ${ }^{44}$.

The $\mathrm{Mn}(\mathrm{II})$ and $\mathrm{Fe}(\mathrm{III})$ complexes with $\mathrm{d}^{5}$ configuration exhibit absorption bands in the region 25320, $33400 \mathrm{~cm}^{-1}$ for $\mathrm{Mn}(\mathrm{II})$ complex and $27000,37000 \mathrm{~cm}^{-1}$ for $\mathrm{Fe}(\mathrm{III})$ complex. These bands may be attributed to number of spin forbidden transitions involving ${ }^{6} \mathrm{~A}_{1 \mathrm{~g}}$ ground state and several higher energy quartet states, which are in consistent with octahedral geometry around $\mathrm{Mn}(\mathrm{II})$ and $\mathrm{Fe}(\mathrm{III})$ metal ions ${ }^{45}$.

The spectrum of Co(II) complex shows two bands at 8348 and $18348 \mathrm{~cm}^{-1}$. These bands are assigned to ${ }^{4} \mathrm{~A}_{2 \mathrm{~g}} \rightarrow{ }^{4} \mathrm{~T}_{1 \mathrm{~g}}(\mathrm{~F})$ and ${ }^{4} \mathrm{~A}_{2 \mathrm{~g}} \rightarrow{ }^{4} \mathrm{~T}_{1 \mathrm{~g}}(\mathrm{P})$ transitions respectively. These transitions are consistent with the proposed tetrahedral geometry to this complex. Further the blue color of the complex supports its proposed tetrahedral disposition.

The spectrum of $\mathrm{Ni}(\mathrm{II})$ complex shows absorption bands in the region 8400, 14730 and $21000 \mathrm{~cm}^{-1}$. The band at $8400 \mathrm{~cm}^{-1}$ is assigned to ${ }^{3} \mathrm{~A}_{2 \mathrm{~g}} \rightarrow{ }^{3} \mathrm{~T}_{2 \mathrm{~g}}$ while the band at 14730 and $21000 \mathrm{~cm}^{-1}$ are assigned to ${ }^{3} \mathrm{~A}_{2 \mathrm{~g}} \rightarrow{ }^{3} \mathrm{~T}_{1 \mathrm{~g}}(\mathrm{~F})$ and ${ }^{3} \mathrm{~A}_{2 \mathrm{~g}} \rightarrow{ }^{3} \mathrm{~T}_{1 \mathrm{~g}}(\mathrm{P})$ transitions respectively in an octahedral geometry ${ }^{46}$.

The spectrum of $\mathrm{Cu}(\mathrm{II})$ complex shows a broad band observed in the region $18181-21978 \mathrm{~cm}^{-1}$. The position and shape of this band suggests the merging of the three electronic transitions i.e., ${ }^{2} \mathrm{~B}_{1 \mathrm{~g}} \rightarrow{ }^{2} \mathrm{~B}_{2 \mathrm{~g}},{ }^{2} \mathrm{~B}_{1 \mathrm{~g}} \rightarrow{ }^{2} \mathrm{~A}_{1 \mathrm{~g}}$ and ${ }^{2} \mathrm{~B}_{1 \mathrm{~g}} \rightarrow{ }^{2} \mathrm{E}$. A square planar geometry is proposed for this complex ${ }^{47,48}$ The black color of the complex further supports its proposed stereochemistry.

The ESR spectrum of $\mathrm{Cu}$ (II) complex was recorded at room temperature. It showed only single broad signal. Hyperfine splitting signals were absent. It shows a $\mathrm{g}_{\mathrm{av}}$ value 2.087, which is consistent with its square planar geometry. The shape of the curve indicates that it has isotropic symmetry. 


\section{Physiological activity}

The culture medium was prepared by the addition of $1.5 \mathrm{~g}$ of Beef extract, $1.5 \mathrm{~g}$ of yeast extract, $5 \mathrm{~g}$ of peptone, $1 \mathrm{~g}$ of dextrose, $3.5 \mathrm{~g}$ of $\mathrm{NaCl}$ and $3.68 \mathrm{~g}$ of dipotassium hydrogen phosphate, $1.32 \mathrm{~g}$ of monopotassium dihydrogen phosphate and $15 \mathrm{~g}$ of agar agar in one liter of water. The $\mathrm{pH}$ of the medium was adjusted to 7.0. The medium is sterilized at $121{ }^{\circ} \mathrm{C}$ in an autoclave at $15 \mathrm{lbs}$ pressure for $15-20 \mathrm{~min}$. The medium was cooled to $45-50{ }^{\circ} \mathrm{C}$. $20 \mathrm{~mL}$ of the medium was poured in each of the petridishes. All the apparatus were sterilized before use. E.coli and S.aureus were introduced into the petriplates and were grown.

\section{Bacteriological testing}

Bacteriological testing was done using paper disc method. Paper discs were soaked in the in DMF solutions of the ligand and the metal complexes. Solutions are prepared in two different concentrations i.e., $100 \mu \mathrm{g} / \mathrm{mL}$ and $1000 \mu \mathrm{g} / \mathrm{mL}$ in DMF. Paper discs were soaked in these solutions. They were dried. The dried paper discs were introduced into the completely grown culture plates of E.coli and S.aureus. The percentage inhibition of the bacteria was calculated by the following equation:

$$
\% \text { Inhibition }=\frac{100(\mathrm{C}-\mathrm{T})}{\mathrm{C}}
$$

Where $\mathrm{C}$ is the diameter $(\mathrm{mm})$ in controlled plates after $72 \mathrm{~h}$ and $\mathrm{T}$ is the diameter in $\mathrm{mm}$ in treated plates after $72 \mathrm{~h}$. From the data it is observed that the ligand shows 8.9 and $44.5 \%$ inhibition at $100 \mu \mathrm{g} / \mathrm{mL}$ and $1000 \mu \mathrm{g} / \mathrm{mL}$. The complexes also show maximum $\%$ inhibition against E.coli. Maximum of $11-20 \%$ in low concentrations and $46-58 \%$ in high concentrations. The order of inhibition is Bavistin $>\mathrm{Cu}(\mathrm{II})>\mathrm{Ni}(\mathrm{II})>\mathrm{Zn}(\mathrm{II})>\mathrm{Co}(\mathrm{II})>$ $\mathrm{Cr}(\mathrm{III})>\mathrm{Mn}(\mathrm{II})>\mathrm{Fe}(\mathrm{III})>$ ligand. The percentage inhibition against S.aureus is $9.5-19 \%$ in the lower concentration and $40-51 \%$ in the higher concentration. The order of inhibition against S.aureus is bavistin $>\mathrm{Ni}$ (II) $>\mathrm{Cu}$ (II) $>\mathrm{Zn}$ (II) $>\mathrm{Mn}$ (II) $>\mathrm{Cr}$ (III) $>\mathrm{Fe}$ (III) $>\mathrm{Co}$ (II) $>$ ligand (Table 2). The antibacterial activity of the ligand and complexes has been less than bavistin. The metal complexes show more physiological activity than the ligand.

Table 2. Fungicidal activity of the ligand and its metal complexes

\begin{tabular}{lcccc}
\hline \multirow{2}{*}{$\begin{array}{c}\text { Ligand/ } \\
\text { Complex }\end{array}$} & \multicolumn{3}{c}{ Percentage inhibition after $72 \mathrm{~h}$, conc. in $\mu \mathrm{g} / \mathrm{mL}$} \\
\cline { 2 - 5 } & \multicolumn{2}{c}{ Escherichia coli } & Staphylococcus.aureus \\
\hline HPBH & 100 & 1000 & 100 & 1000 \\
Cr(III) complex & 15 & 44.5 & 9.5 & 40 \\
Mn(II) complex & 13 & 50 & 12 & 45 \\
Fe(III) complex & 11 & 49 & 14 & 47 \\
Co (II) complex & 16 & 52 & 11 & 43 \\
Ni (II) complex & 18 & 56 & 10 & 41 \\
Cu (II) complex & 20 & 58 & 19 & 51 \\
Zn (II) complex & 17 & 54 & 16 & 50 \\
Bavistin & 82 & 100 & 87 & 48 \\
\hline
\end{tabular}

\section{Conclusion}

Octahedral geometry is proposed for $\mathrm{Cr}(\mathrm{III}), \mathrm{Fe}(\mathrm{III}) \mathrm{Mn}(\mathrm{II}), \mathrm{Ni}(\mathrm{II})$ and $\mathrm{Zn}$ (II) complexes (Figure 3). A square planar disposition is proposed for $\mathrm{Cu}(\mathrm{II})$ complex (Figure 4) and a tetrahedral geometry has been given for $\mathrm{Co}$ (II) complex (Figure 5). 


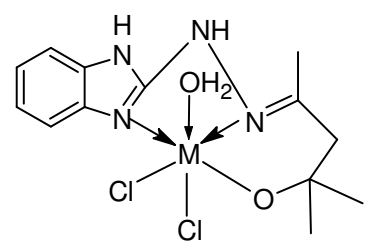

Figure 3. Structure of metal complexes, where $\mathrm{M}=\mathrm{Cr}$ (III) and $\mathrm{Fe}(\mathrm{III})$

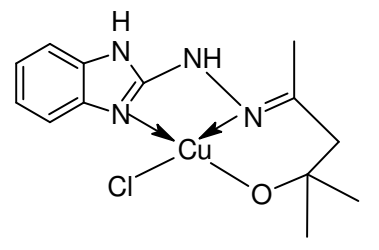

Figure 4. Structure of $\mathrm{Cu}(\mathrm{II})$ complex

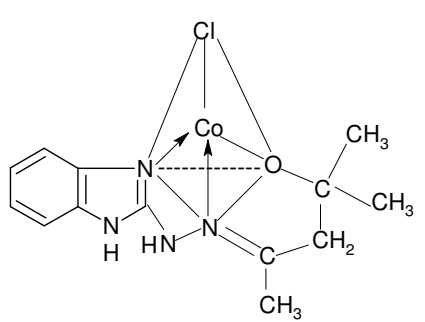

Figure 5. Structure of $\mathrm{Co}(\mathrm{II})$ complex

\section{Acknowledgements}

One of the authors Neelamma is indebted to GATE (UGC), New Delhi for financial assistance. The authors are also thankful to the Head, Department of Microbiology and O.U. for anti bacterial screening and Head, Department of Chemistry for recording IR spectra, magnetic susceptibility measurements and for providing facilities.

\section{References}

1. Heinrich L, Mary-Verla A, Vaissermann J, Chottard J C and Li Y, Inorg Chim Acta, 2004, 357, 2462-2465.

2. Venkatraman R, Haamid A, Lungile S, Erick Ellis, Frank R F and Edward J V, $J$ Chem Crystallogr., 2009, 39(10), 711-718.

3. Nagwa Nawar and Nasser Mohamed Hosney, Chem Pharm Bull., 1999, 47(7), 944-949.

4. El Manakhly K, Shabana A and Hammad H, J Indian Chem Soc., 1997, 74, 715-718.

5. Ainscough Eric W, Brodie A M, Denny William A, Finlay Graeme J, Gothe Scott A and Ranford J D, J Inorg Biochem., 1999, 77(3-4),125-133.

6. Carcelli M, Mazza P, Pellizi C and Zani F, J Inorg Biochem., 1995, 57(1), 43-62.

7. Aggarwal R C and Rao T R, J Inorg Nucl Chem., 1978, 40(1),171-174.

8. Tossadis I A, Bolos C A, Aslanidis P N, Katsoulos G A, Inorg Chim Acta, 1987, 133, 275-278.

9. Anten J A, Nicholis D, Markopoulos J M and Markopoulos O, Polyhedron, 1987, 6, 1074.

10. Maiti A and Ghosh S, Indian J Chem., 1989, 28A, 980-983.

11. Emara Adel A A, El-Sayed B A and Ahmed El -Sayed A E, Spectrochim Acta Part A, Molecular and Biomolecular Spectroscopy, 2008, 69(3), 757.

12. Abd El Wahed M G, Bayoumi H A and Mohammed M I, Bull Korean Chem Soc., 2003, 24 (9), 1313-1315.

13. Tossadis A, Bolos C A, Aslandidis P N and Katsoulos G A, Inorg Chim Acta,1987, 133, 275-278.

14. Anten D, Nicholis J M, Markopoulos O and Morkopoulou, Polyhedron, 1987, 6, 1074-1077.

15. Sanyal G S and Garai S, Indian J Chem., 1991, 30A, 375-377.

16. Rao T R, Sahay M and Aggarwal R C, Synth React Inorg Met-Org Chem, 1985, 15, 209.

17. Abd-Elmotaleb M, Erian I E, Bassett M A and Ibrahim S A, Bulletin of Faculty of Science, Assiut University, B: Chemistry, 2002, 31(1), 25-29.

18 M. Abd - Elmotaleb, M. A. I. El- Erian, M. A. Bassett, S.A Ibrahim, Bulletin of Faculty of Science, Assiut University, B: Chemistry, 2001, 30(2), 11-14.

19. Wang Yan, Zheng, Yin Yang and Bao Dui Wang, Synth React Inorg Met Org NanoMet Chem., 2005, 35, 237-241. 
20. Galal Shadia A, Hegeb Khaled H, Hashem Ahmed M and Youssef Nabil S, Eur J Med Chem., 2010, 45(12), 5685.

21. Mohamed, Gehad G, Ibrahim Nasser A and Attia Hanaa A E, Spectrochim Acta Part A, Molecular and Biomolecular Spectroscopy, 2009, 72(3), 610.

22. Bharti Neelam, Shailendra, Gonzalez Garza M T, CruzVega Delia E, Castro Gazza J, Saleem Kishwar and Naqv Fehmida Azam Amir, Bioinorgnic Medicinal Chem Lett., 2002, 123(6), 869.

23. Mashaly Mohd M, Ismail T M, El-Maraghy S B and Habib H A, J Coord Chem., 2003, 56(15), 1307-1309.

24. El-Sherif Ahmed and Jeragh Bakir J A, Spectrochim Acta, Part A Molecular and Biomolecular Spectroscopy, 2007, 68(3), 877.

25. Michael D, Malachy Mc C, Dennis O, Rachel K, Denise E and Carol D J, Inorg Biochem., 2004, 98, 1023-1026.

26. Salem M H N, Synth React Inorg Met Org Nano-Met Chem., 2005, 35, 369-373.

27. Easmon J, Puerstinger G, Thomas Roth, Fiebig H H, Jenny M, Jaegar W, Heinisch G and Hofmann Johann, Int J Cancer, 2001, 94(1), 89-93.

28. Richardson D R, Kalinowski D S, Lau S, Jansson P J and Lovejoy D B, Biochimica et Biophysica Acta (BBA), 2009, 1790(7), 702.

29. Craliz J C, Rub J C, Willis D and Edger J, Nature, 1955, 34, 176.

30. Dilworth J R, Coord Chem Rev., 1976, 21, 29-37.

31. Mashalay M M, El-Shafiy H F, El-Maraghy S B, Habib H A, Spectrochimica Acta, Mol Bimol Spectrosc., 2005, 61A(8), 1853-1858.

32. Povstyanoi M V, Kruglenko V P and Povstyanoi V M, Chem Heterocycl Comp., 2001, 37(1), 120-123.

33. Silverstein R M, Bassler G C, Morrill T C, Spectrometric Identification of Organic Compounds, $5^{\text {th }}$ Ed., John Wiley \& Sons, Inc., N Y, 1991, 183.

34. Nakamoto K, Infrared and Raman spectra of Inorganic and Coordination Compounds, Part B, $5^{\text {th }}$ Ed., John Wiley: New York, 1997, 159.

35. Benabdallah T, All Hasoon, Al-talar, Hassnia and Reffas, S Afr J Chem., 2004, 57, 33-35.

36. Sulekh Chandra and Lokesh Kumar Gupta, J Indian Chem Soc., 2004, 81, 739-742.

37. Mane P S, Shirodkar S G, Arbad B R and Chondhekar T K, Indian J Chem., 2001, 40A, 648-652.

38. Bellamy L J, Infrared Spectra of Complex Molecules, Vol II, $2^{\text {nd }}$ Ed., Chapman and Hall: New York, 1980.

39. Petr Danecek, Josef Kapitan, Vladimir Kopecky Jr and Petr Bour, J Chem Phys., 2007, 126(22), 224513.

40. Rana V B, Singh P, Singh D P and Teotia M P, Polyhedron, 1982, 1, 377-380.

41. Hankare P P, Naravane S R, Bhuse V M, Delekar S D and Jagtap A H, Indian J Chem., 2004, 43A, 1464-1468.

42. Ferenc W, Bocian B and Walkow-Dziewulskal A, J Serb Chem Soc., 2004, 69(3), 195-204.

43. Rajiv Kumar and Rajeev Singh, Turk J Chem., 2006, 30, 77-81.

44. Demirhan N, Ibrahim Erden and Ulvi Avciata, Indian J Chem., 2004, 43A, 782-785.

45. Ballhausen C J, Introduction to Ligand Field Theory, McGraw Hill, New York, 1962.

46. Lever A B P, Inorganic Electronic Spectroscopy, Elsevier, Amsterdam, 1968.

47. Kamruddin S K and Roy A, Indian J Chem., 2001, 40A, 211-214.

48. Lata N, Manisha Gupta and Pavan Mathur, Indian J Chem., 2001, 40A, 247-250. 


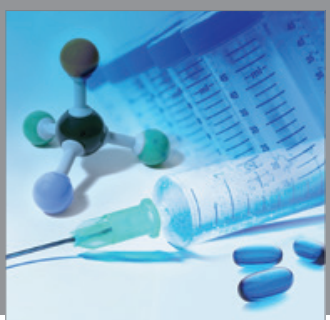

International Journal of

Medicinal Chemistry

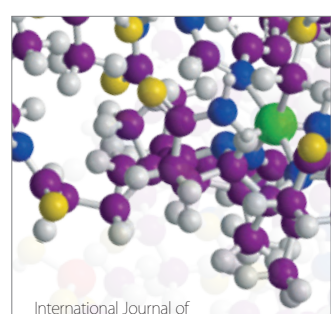

Carbohydrate Chemistry

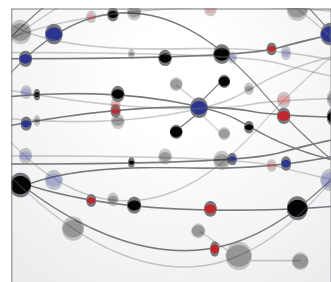

The Scientific World Journal
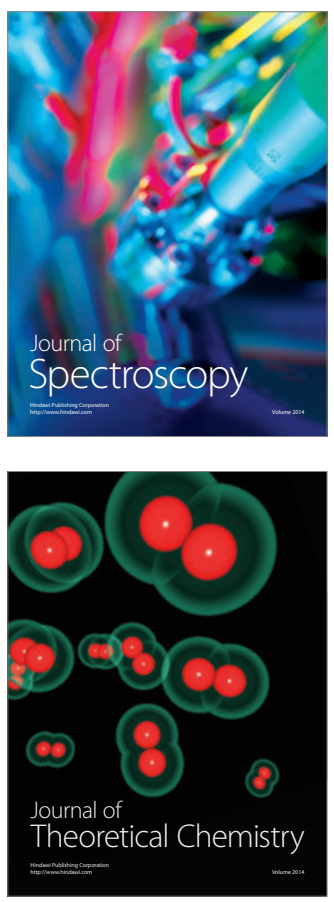
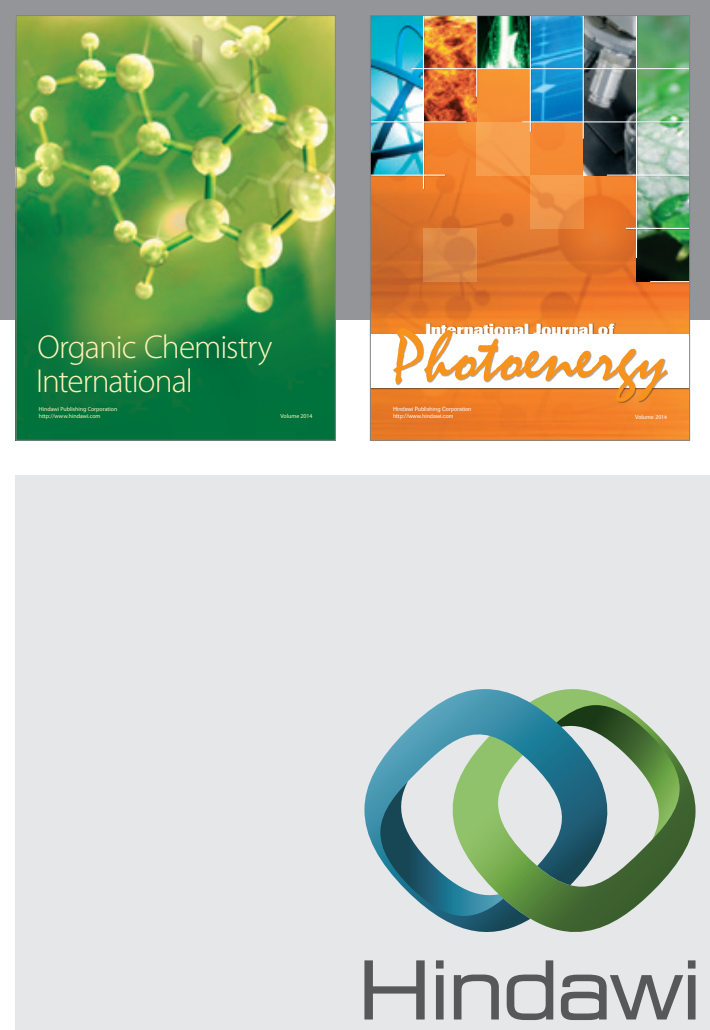

Submit your manuscripts at

http://www.hindawi.com
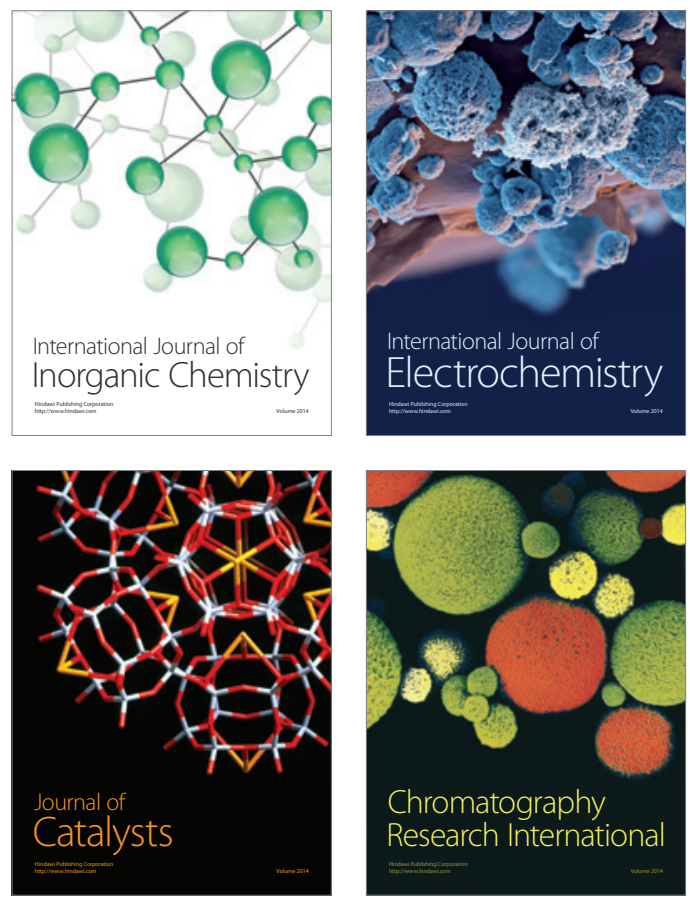
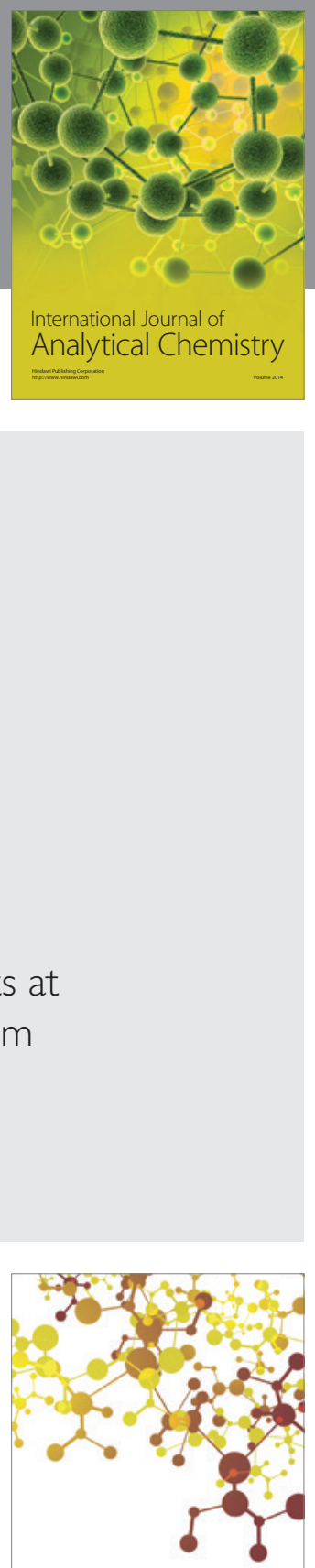

Journal of

Applied Chemistry
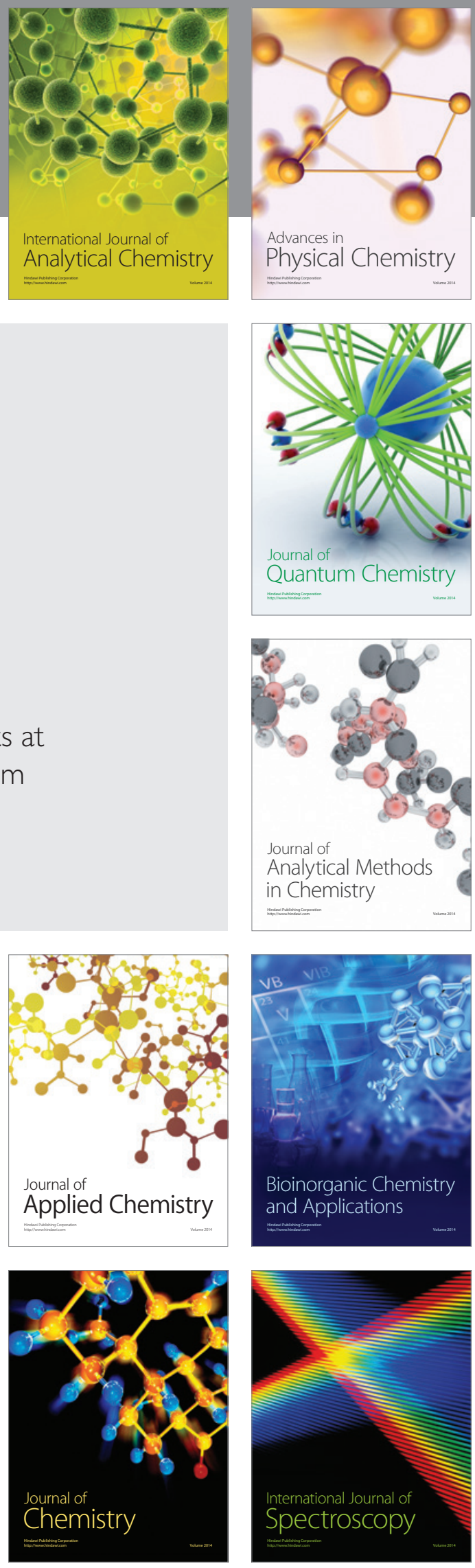